\title{
Product strategy and promotional strategies of Copsy coffee
}

\author{
HAWALDAR SUHAS MAHADEO, NETHRAVATHI ASHOK PATIL, LAXMI N. TIRLAPUR AND \\ SHREYA V. AMARAPURKAR
}

\begin{abstract}
Coffee is the most popular beverages with over 400 billion cups consumed yearly. There are many brands in coffee business offering range of products as Instant coffee, conventional coffee etc. based on varied and distinct taste of consumers. Bru, Green Label, Nescafe, Cothas etc. are national level brands and few local brands are also present. Copsy coffee is a local brand promoted by Arehally Coffee Growers Co-operative Society. The present study was conducted to analyse the analyse the brand launching and promotional strategies of Copsy coffee and the product strategy and to assess the sales, distribution and pricing strategies of Copsy coffee. The data was collected from 180 consumers from Hassan, Mysore and Bangalore city using pre tested structured schedule. The brand was launched with much fan fare by endorsing film star Puneeth Rajkumar. Advertisement through TV followed by leaflets was well received by consumers. The society not adopted any sales, pricing and distribution strategies.Taste is the most important factor followed by brand name that influences a consumer's brand preference decision and women are the decision maker in the preference of coffee brands. The vast majority of consumers liked taste of Copsy Coffee as most preferred trait, quality as excellent, price as on par with market, rating the overall brand as an excellent.
\end{abstract}

KEY WORDS : Promotional strategies, Media, Pricing

How to cite this paper : Mahadeo, Hawaldar Suhas, Patil, Nethravathi Ashok, Tirlapur, Laxmi N. and Amarapurkar, Shreya V. (2015). Product strategy and promotional strategies of Copsy coffee. Internat. J. Com. \& Bus. Manage, 8(2) : 237-243. Agricultural Sciences, BENGALURU (KARNATAKA) INDIA 